\title{
Penerapan prinsip pengajaran Bahasa Tionghoa sebagai bahasa kedua pada mata kuliah Percakapan 3 di jurusan S-1 Sastra Cina di Universitas X Bandung
}

\author{
Preyi Vencania Lumanda \\ Jurusan S-1 Sastra China, Fakultas Sastra, Universitas Kristen Maranatha, Bandung \\ preyivencania@gmail.com
}

\begin{abstract}
Abstrak
Semakin banyaknya permintaan akan pembelajaran bahasa Tionghoa akan membuat peran pengajar semakin penting. Pengajar akan mentransfer ilmu yang dimilikinya kepada peserta didiknya, oleh karena itu pengajar perlu untuk menyusun suatu rancangan pembelajaran semester yang efektif. Rancangan pembelajaran semester yang efektif akan meningkatkan kualitas belajar peserta didik dan memperdekat hubungan pengajar dan peserta didik, selain itu juga akan meningkatkan animo masyarakat yang tertarik untuk mempelajari bahasa Tionghoa. Pengajaran Bahasa Tionghoa sebagai bahasa kedua sangat penting mengingat bahasa Tionghoa bukanlah bahasa ibu masyarakat Indonesia dan Bandung pada khususnya. Penulis yang juga merupakan salah satu pengajar di perguruan tinggi menyusun sebuah rancangan pembelajaran semester yang telah dipraktikkan pelaksanaannya, dan hasil yang didapat menunjukkan rancangan yang disusun masih belum mendapatkan hasil yang maksimal. Hal ini disebabkan oleh beberapa faktor seperti pengaturan jam kuliah, beban studi yang ditempuh oleh mahasiswa/i, pemberian tugas dan soal ujian praktik yang diberikan, dan hal-hal lain yang tidak terpikirkan sebelumnya oleh penulis.
\end{abstract}

Kata kunci : Bahasa Tionghoa, rancangan pembelajaran semester, Bahasa Tionghoa sebagai bahasa kedua, proses pembelajaran, proses pengajaran.

\begin{abstract}
The increasing demand on Chinese language lesson will make the role of Chinese language teacher become more important. The teacher will transfer the knowledge that he/she has to his/her learner. Therefore, the teacher needs to compile an effective semester learning draft. An effective semester learning draft will enhance the quality of teaching, create a closer relationship between the teacher and learner, and also will increase public interest in learning Chinese language. The teaching of Chinese language as second language is very important considering that Chinese language is not the mother tongue of Indonesian and especially Bandung people. The writer who is also a lecturer in a university compiled a semester teaching draft, practiced it, found out that the compiled draft still cannot achieve the expected result. There are several factors that affect the result, such as: the arrangement of lecture schedule, the students' study loads, the assignments and practice tests that's given, and other factors that's beyond the writer's thought.
\end{abstract}

Keywords :Chinese language, teaching draft, Chinese as a second language, learning process, teaching process 


\section{A. Pendahuluan}

Seiring dengan pertumbuhan ekonomi negara Repulik Rakyat Tiongkok yang semakin pesat, semakin banyak orang yang ingin mempelajari Bahasa Tionghoa. Ada sebagian orang yang mempunyai kesempatan untuk belajar Bahasa Tionghoa langsung ke negara Tiongkok bahkan dapat merasakan sendiri keistimewaan dan kebesaran budaya Tiongkok. Namun tidak semua orang memiliki kesempatan untuk belajar Bahasa Tionghoa langsung di Tiongkok, sebagian dari mereka memilih untuk mempelajarinya di institusi/perguruan tinggi Indonesia. Universitas X sebagai perguruan tinggi di Bandung yang memiliki program studi S-1 Sastra Cina merupakan pilihan yang tepat bagi peserta didik di Bandung.

Jurusan S-1 Sastra Cina Universitas X Bandung menitikberatkan pengajaran Bahasa Tionghoa pada 4 keterampilan utama yaitu mendengar, berbicara, membaca, dan menulis. Berbicara merupakan salah satu unsur yang paling penting dalam Bahasa Tionghoa, oleh karena itu mata kuliah percakapan memegang peranan yang sangat penting dalam proses pembelajaran Bahasa Tionghoa karena digunakan dalam komunikasi sehari-hari. Proses pengajaran percakapan harus disertai dengan teknik yang tepat agar bisa meningkatkan motivasi belajar peserta didik dan dapat meningkatkan kemampuan berbicara peserta didik dengan lebih efektif.

Salah satu teknik yang dapat digunakan adalah teknik pengajaran Bahasa Tionghoa sebagai bahasa kedua. Teknik pengajaran Bahasa Tionghoa sebagai bahasa kedua dapat meningkatkan motivasi peserta didik, juga dapat membuat suasana pengajaran dan pembelajaran di kelas menjadi lebih menyenangkan, lebih bebas dari tekanan, dan melibatkan peserta didik secara penuh. Penulis sebagai pengajar mata kuliah percakapan juga menerapkan teknik pengajaran Bahasa Tionghoa sebagai bahasa kedua di dalam kelas dan dari hasil proses belajar dan mengajar di semester 3 ini dapat dilihat efektifitas penerapan teknik pengajaran Bahasa Tionghoa sebagai bahasa kedua.

\section{B. Landasan Teori}

\subsection{Sifat dasar dari aktivitas berbicara}

Menurut ilmu psikolinguistik, aktivitas berbicara dikontrol oleh pusat bahasa di dalam otak manusia, ketika muncul hasrat untuk berbicara, pusat bahasa di dalam otak manusia akan beraktivitas terlebih dahulu, mencari informasi bahasa yang tersimpan dalam otak manusia kemudian mengeluarkannya, mengurutkannya sesuai dengan urutan yang tepat, mengungkapkan dalam hati manusia kemudian dikeluarkan melalui organ pengucapan 
Vol.1, No.2, Oktober 2017, PP.1-13

manusia, mengubah informasi bahasa menjadi bahasa yang bersuara, keseluruhan aktivitas berbicara adalah proses menransfer dan mengodekan informasi bahasa.

\subsection{Bahasa Tionghoa lisan}

Bahasa Tionghoa yang dibicarakan disebut juga dengan Bahasa Tionghoa lisan. Yang dimaksud dengan Bahasa Tionghoa lisan adalah menerima dan menyampaikan informasi melalui suara dan sistem pendengaran. Bahasa Tionghoa lisan memiliki beberapa keistimewaan seperti di bawah ini:

1. Memiliki perubahan intonasi, ekspresi, dan berat ringannya bunyi.

2. Kalimatnya tidak harus utuh, memiliki jeda dan pengulangan.

3. Memiliki bagian yang menyimpang, tidak tepat ataupun bertele-tele.

4. Panjang pendeknya kalimat dan struktur gramatikal sederhana, tidak banyak atribut, lebih sedikit menggunakan kata sambung.

5. Frekuensi pemakaian kalimat yang disingkat, kalimat yang berubah polanya, kalimat yang terbalik polanya, dan juga kalimat retoris lebih banyak.

6. Pemakaian kata lebih sederhana dan mudah dimengerti.

7. Frekuensi pemakaian kalimat-kalimat populer lebih tinggi.

8. Sangat sering memakai perumpamaan.

Tujuan pengajaran Bahasa Tionghoa lisan adalah memupuk kemampuan berkomunikasi, mengutamakan penyampaian secara lisan, jadi yang diajarkan seharusnya adalah "kalimatkalimat yang diucapkan oleh manusia". Pengajaran percakapan seharusnya mengajarkan Bahasa Tionghoa yang dibicarakan, jadi jangan sampai membawa ragam bahasa tulisan seperti contoh di bawah ini :

$A$ ：你这么忙，还来送我们，这使我非常感动。

Kamu sesibuk ini, masih datang untuk mengantar kami, ini membuat saya sangat terharu.

$B$ ：为朋友送行是件愉快的事情。

Dapat mengantarkan kepergian teman adalah suatu hal yang menyenangkan.

$\mathrm{A}$ : 在这短短的时间里, 我们既提高了汉语水平, 又游览了名胜古迹, 就要离 开这里了, 我还真有点儿舍不得呢!

Dalam waktu yang sangat singkat ini, kami selain dapat meningkatkan kemampuan Bahasa Tionghoa, juga telah mengunjungi tempat bersejarah, 
sekarang sudah akan meninggalkan tempat ini, saya benar-benar merasa berat untuk meninggalkannya.

B：学习虽然结束了, 我们之间的友谊却是刚刚开始。

Meskipun pembelajarannya sudah selesai, tapi pertemanan kita baru mulai.

Dalam komunikasi yang sebenarnya, kalimat seperti “这使我非常感动(ini membuat saya sangat terharu)”, “我们既提高了汉语水平, 又游览了名胜古迹(kami selain dapat meningkatkan kemampuan Bahasa Tionghoa, juga telah mengunjungi tempat bersejarah)", dan “我们之间的友谊却是刚刚开始(tapi pertemanan kita baru mulai)” jika dituliskan dalam surat akan terlihat sangat alami, tapi jika dalam komunikasi tatap muka justru tidak diucapkan seperti ini. Jika mengajarkan "Bahasa Tionghoa yang dibicarakan" tapi mengandung nuansa tertulis seperti ini kepada peserta didik jelas tidak tepat.

\subsection{Latihan keterampilan berbicara dalam Bahasa Tionghoa}

\section{Prinsip latihan keterampilan berbicara}

Yang Huiyuan (2007) mengemukakan latihan berbicara seharusnya melaksanakan prinsip komunikatif. Yang dimaksud dengan prinsip komunikatif adalah bertolak dari tujuan komunikasi kemudian memberikan bimbingan untuk latihan berbicara, agar bisa meningkatkan tujuan dari kemampuan berkomunikasi. Intinya adalah semua aktivitas yang ada dalam kelas digunakan untuk latihan keterampilan berbicara peserta didik.

\section{Pembagian tingkat dan pembagian tujuan latihan berbicara}

Tujuan dari pengajaran Bahasa Tionghoa sebagai bahasa kedua adalah membina kemampuan berkomunikasi. Fan Kaiqin mengemukakan kemampuan berkomunikasi Bahasa Tionghoa harus mencakup 3 hal ini:

A. Kemampuan sistem Bahasa Tionghoa. Pemakaiannya harus memenuhi syarat gramatikal dan dapat diterima.

B. Kemampuan penyampaian Bahasa Tionghoa yang layak. Memilih cara penyampaian yang paling tepat dengan melihat konteks ketika pembicaraan sedang berlangsung dan kondisi pembicara dan pendengar.

C. Kemampuan beradaptasi dengan kebudayaan China. Ketika berkomunikasi dengan Bahasa Tionghoa, pembicara juga dapat menyesuaikan dengan kebiasaan sosial dan budaya masyarakat Tiongkok.

Tujuan latihan keterampilan lisan Bahasa Tionghoa adalah membina kemampuan komunikasi lisan peserta didik . Kepala departemen pengembangan dan promosi internasional 
Hanban Tiongkok merumuskan "Garis besar Pembelajaran Umum pengajaran Bahasa Tionghoa internasional" yang membagi keterampilan bahasa ke dalam 5 tingkat dan menggambarkan tujuan masing-masing keterampilan di masing-masing tingkat, seperti di bawah ini:

\section{Tingkat 1}

A. Dapat mengulangi apa yang dibacakan, mengulangi atau membaca kata dan kalimat yang sudah dipelajari dengan ton tepat.

B. Dapat menyebutkan identitas pribadi.

C. Dapat menyapa orang lain dengan inisiatif atau dapat membalas sapaan orang lain.

D. Dapat menyampaikan keperluan atau instruksi yang paling dasar menggunakan kata atau kalimat yang sederhana.

E. Dapat menyampaikan permohonan atau permintaan tolong yang paling dasar.

\section{Tingkat 2}

A. Dapat menggunakan kalimat yang paling sederhana untuk mengenalkan diri sendiri atau orang lain.

B. Dapat menggunakan bahasa sehari-hari untuk berkomunikasi dengan orang lain, mengajukan pertanyaan dan menjawab pertanyaan dengan kalimat sederhana

C. Dapat memberikan petunjuk, mengajukan permintaan, dan meminta pertolongan kepada orang lain dalam kondisi akrab.

D. Dapat menunjukkan sikap dan suasana hati yang tepat dalam kesempatan yang berbeda

\section{Tingkat 3}

A. Dapat menggunakan tekanan, jeda, intonasi atau bahasa tubuh untuk memperkuat ekspresi.

B. Ikut serta dalam perbincangan sehari-hari dan membicarakan permintaan pribadi.

C. Dapat mengadakan komunikasi dengan orang lain dengan menggunakan topik sehari-hari atau topik yang sudah dikuasai dalam proses pembelajaran atau membuat pernyataan sederhana. 
D. Dapat mendeskripsikan secara sederhana hal-hal, kegiatan ataupun pengalaman pribadi yang sering ditemui dalam kehidupan sehari-hari.

E. Dapat menunjukkan sikap yang jelas kepada hal-hal, fenomena atau kondisi tertentu dalam kehidupan sehari-hari.

F. Dapat menceritakan cerita singkat.

\section{Tingkat 4}

A. Dapat berkomunikasi mengenai topik pembicaraan umum dengan orang lain di suatu tempat dan kesempatan tertentu.

B. Dapat mengikuti diskusi sederhana, dapat mengemukakan pandangan pribadi secara jelas.

C. Dapat mengemukakan saran atau kritik mengenai suatu hal serta mampu memberikan alasannya.

D. Dapat menggunakan strategi komunikasi yang paling dasar, penjelasannya jelas dan berkesinambungan.

E. Dapat mengurusi keperluan sehari-hari, mengatur atau memberikan petunjuk.

F. Dapat menceritakan atau melaporkan keseluruhan suatu kejadian dengan lebih lengkap.

\section{Tingkat 5}

A. Dapat berkomunikasi secara efektif mengenai topik pembicaraan umum dengan orang lain di suatu tempat dan kesempatan yang berbeda.

B. Dapat menguraikan topik pembicaraan yang disenangi, cara penyampaian jelas dan kalimat berkesinambungan.

C. Dapat berbincang mengenai topik pembicaraan tertentu dengan lebih mendalam.

D. Ikut serta dalam diskusi atau debat, dapat menjelaskan pandangan pribadi secara jelas, dan membantah pandangan orang lain.

\subsection{Teknik pengajaran Bahasa Tionghoa sebagai bahasa kedua}

Pengajar dapat memilih teknik pengajaran yang sesuai dengan jenis kelas dan peserta didiknya. Teknik pengajaran yang dipilih dapat berdasarkan 4 prinsip yaitu : prinsip praktek, prinsip komunikasi, prinsip tujuan, dan prinsip efektivitas waktu. Dalam prinsip praktek, pengajar membiarkan peserta didik untuk lebih banyak mempraktekkan percakapan di dalam kelas. Pengajar harus memberikan kesempatan kepada peserta didik untuk lebih banyak berbicara dan lebih banyak latihan. Petunjuk yang diberikan oleh pengajar kepada peserta didik pun harus seminimal mungkin. Begitu juga dengan prinsip komunikasi. Pengajar 
memilih latihan yang dapat meningkatkan kemampuan komunikasi peserta didik. Pengajar harus memilih latihan yang dapat lebih cepat mencapai tujuan dari inti materi. Setiap tujuan yang berbeda akan menggunakan cara yang berbeda. Yang terakhir adalah prinsip efektivitas waktu, pengajar harus memanfaatkan waktu dengan secepat mungkin agar dapat mencapai tujuan pengajaran. Pengajar harus meluangkan lebih banyak waktu untuk berlatihan semaksimal mungkin di dalam ruang kelas.

\section{METODE PENELITIAN DAN PEMBAHASAN}

\subsection{Metode Penelitian}

Sampel yang digunakan dalam penelitian ini adalah seluruh mahasiswa/i yang menempuh mata kuliah Percakapan 3 yaitu sebanyak 22 orang. Mahasiswa/i ini merupakan mahasiswa tingkat dasar yang dapat menempuh mata kuliah ini setelah lulus dari mata kuliah percakapan 1 dan percakapan 2. Seluruh proses belajar dan mengajar mengikuti rancangan pembelajaran semester yang penulis susun dan data yang digunakan adalah nilai-nilai yang didapatkan dari praktik percakapan keseharian, nilai ujian tengah dan akhir semester.

Dari data yang didapat, penulis akan melakukan analisis mengenai apakah rancangan pembelajaran semester yang telah disusun dan dipraktikkan dapat meningkatkan minat dan prestasi belajar mahasiswa/i di universitas X.

\subsection{Bahan Ajar}

Bahan ajar yang digunakan pada mata kuliah percakapan 3 adalah Fazhan Hanyu Zhongji Koиyu I yang diterbitkan oleh Beijing Language and Culture University Press. Bahan ajar ini disusun untuk mahasiswa yang sedang merencanakan atau sudah belajar Bahasa Tionghoa di Tiongkok. Bahan ajar ini dapat digunakan oleh mahasiswa yang sudah menguasai kurang lebih 2000-2500 kosakata sehari-hari Bahasa Tionghoa. Tujuan dari penyusunan bahan ajar ini adalah meningkatkan kemampuan percakapan peserta didik dengan lebih efektif, terutama dalam percakapan sehari-hari. Bahan ajar ini juga memilliki kelebihan yaitu pemilihan materi disesuaikan dengan kehidupan sehari-hari tapi juga kaya akan pengetahuan umum. Latihan yang disusun adalah latihan yang mengutamakan prinsip komunikasi agar peserta didik dapat berlatih dengan lebih banyak.

Fazhan Hапуи Zhongji Коиуи I total terdiri dari 15 bab dengan rincian bab sebagai berikut:

Tabel 1 Rincian bab dalam buku Fazhan Hanyu Zhongji Kouyu I

\begin{tabular}{|l|l|}
\hline Bab 1 Hari pertama & Bab 2 Mengikuti adat-istiadat setempat \\
\hline Bab 3 Kampung halaman & Bab 4 Pergi atau tinggal \\
\hline Bab 5 workaholic & Bab 6 Unit Kegiatan Mahasiswa \\
\hline
\end{tabular}




\begin{tabular}{|l|l|}
\hline Bab 7 Mentraktir & Bab 8 Retur barang \\
\hline Bab 9 Menyewa rumah & Bab 10 Percaya atau tidak percaya \\
\hline Bab 11 Belajar dan ujian & Bab 12 Belajar sambil bekerja \\
\hline Bab 13 Melakukan perjalanan & Bab 14 Membaca buku apa \\
\hline Bab 15 Yang paling sulit dilupakan & \\
\hline
\end{tabular}

Di masing-masing bab ini terdapat 2 teks bacaan yang sesuai dengan tema masing-masing bab. Setiap bab akan dimulai dengan kosakata baru teks bacaan, menjawab pertanyaan sesuai dengan teks bacaan, latihan bertanya dan menjawab, mengisi bagian yang kosong dengan jawaban benar dan beberapa latihan.

\subsection{Rancangan pengajaran dan hasil pembelajaran sampai sebelum Ujian Tengah Semester}

Penulis menyusun suatu rancangan pengajaran yang sesuai dengan teori-teori pengajaran keterampilan berbicara Bahasa Tionghoa sebagai bahasa kedua dengan teknik-teknik pengajaran yang diharapkan dapat lebih meningkatkan minat dan motivasi belajar mereka, sehingga mereka dapat lebih terampil dalam percakapan.

Dari keseluruhan bab yang ada di dalam bahan ajar, pengajar membuat rancangan untuk mengajarkan 10 bab yang dimulai dari bab 1 hingga bab 10. Pengaturan pengajaran bahan ajar tersebut dibagi menjadi 2 bagian besar, yaitu bab 1 hingga bab 5 diajarkan mulai dari pertemuan pertama hingga ujian tengah semester, bab 6 hingga bab 10 diajarkan mulai dari pertemuan pertama setelah ujian tengah semester hingga ujian akhir semester. Tidak semua bab di dalam bahan ajar ini dapat diajarkan karena keterbatasan jumlah pertemuan, jumlah peserta didik yang cukup banyak, dan ingin memaksimalkan kemampuan peserta didik dalam menerima materi ajar.

Rancangan bagian 1 yang disusun oleh penulis dimulai dari bab 1 hingga bab 5. Dalam bab 1 hingga bab 5 ini, prinsip pengajaran yang digunakan oleh penulis adalah prinsip praktek,prinsip komunikasi, dan prinsip efektifitas waktu. Metode-metode yang digunakan mencakup metode ceramah, latihan keterampilan, diskusi, demonstrasi. Tugas-tugas yang diberikan kepada peserta didik mencakup monolog, dialog, presentasi kelompok, drama singkat, menyanyikan lagu, dan diskusi kelompok. Dari proses pengajaran dan pembelajaran yang telah dilaksanakan seperti monolog dan menyanyikan lagu sudah memenuhi salah satu prinsip pengajaran Bahasa Tionghoa sebagai bahasa kedua yaitu prinsip praktek. Pengajar selain memberikan waktu untuk peserta didik memahami teks dan latihan-latihan yang ada di buku teks, juga memiliki kesempatan dan waktu yang lebih banyak untuk berlatih. Peserta didik dapat menyusun kalimat-kalimat dengan tata bahasa yang benar untuk dipraktekkan menjadi monolog dan dipersembahkan di hadapan pengajar dan teman. Dengan demikian, 
dapat memicu kepercayaan diri peserta didik dan sekaligus juga menjadi kesempatan pengajar untuk membenarkan intonasi dan ton yang kurang tepat dari peserta didik, tentunya pembenaran ini harus dilakukan dengan cara yang tepat tanpa mengurangi rasa kepercayaan diri peserta didik. Selain prinsip praktek, prinsip komunikasi juga diterapkan dalam proses ini, yaitu dengan tugas dialog, presentasi kelompok, drama singkat, dan diskusi kelompok. Tugastugas ini diberikan dengan tujuan peserta didik selain dapat melakukan komunikasi satu arah juga dapat melakukan komunikasi dua arah. Dengan adanya dialog, peserta didik dapat melatih responnya dalam mendengar dan membalas kalimat dari lawan bicara, dengan demikian kemampuan pemahaman lisannya juga turut terlatih. Untuk memberikan suasana yang lebih nyata dalam proses pengajaran dan pembelajaran, peserta didik diminta untuk melakukan drama singkat dengan kisaran waktu 3-6menit. Tema yang diberikan adalah bertamu ke rumah orang Tiongkok. Di sini peserta didik dilatih kemampuan berpikirnya untuk memikirkan buah tangan apa saja yang boleh diberikan kepada tuan rumah dan apa yang tidak boleh diberikan. Dengan drama ini, peserta didik dapat merasakan suasana yang lebih nyata dibandingkan dengan latihan dialog. Presentasi kelompok dan diskusi kelompok diberikan dengan tujuan lebih melatih kemampuan komunikasi lisan peserta didik. Melalui presentasi dan diskusi kelompok, peserta didik dihadapkan dengan pertanyaan-pertanyaan dan respon yang sebelumnya tidak pernah disiapkan oleh peserta didik, sehingga dapat lebih melatih kemampuan analisis peserta didik dan peserta didik juga dapat merangkai kalimat-kalimat lisan dari hasil analisisnya. Di sini peserta didik dilatih untuk lebih bisa memberikan respon terhadap sesuatu yang sifatnya lebih mendadak. Metode yang digunakan dan tugas yang diberikan mengacu pada prinsip efektifitas waktu, oleh karena itu sebagian tugas ada yang diberikan kepada masing-masing peserta didik dan ada tugas yang diberikan secara berkelompok. Bagaimana pun juga, waktu yang tersedia cukup terbatas dan materi yang harus diajarkan cukup banyak sehingga efektiftas waktu harus diperhatikan.

Dari proses pengajaran dan pembelajaran selama 12 pertemuan ini, ujian tengah semester dirancang menjadi 3 bagian yaitu:

1. Drama singkat sesuai dengan tema yang ada di buku teks.

2. Monolog mengenai tema bab 3 dengan kisaran waktu 3-5menit.

3. Merespon kalimat atau pertanyaan yang diberikan oleh pengajar.

Setelah ujian tengah semester, didapatkan hasil ujian peserta didik dengan data yang tercantum dalam tabel di bawah ini:

Tabel 2: Hasil Ujian Tengah Semester mahasiswa/i semester Ganjil 2015/2016

\begin{tabular}{|l|l|l|l|} 
No & Standar nilai & Jumlah Peserta Didik & Transkip Nilai \\
\hline
\end{tabular}




\begin{tabular}{|c|c|c|c|}
\hline 1 & $n<41$ & 0 & $E$ \\
\hline 2 & $41 \leq n<55$ & 0 & $D$ \\
\hline 3 & $55 \leq n<61$ & 2 & $C+$ \\
\hline 4 & $61 \leq n<67$ & 2 & $C$ \\
\hline 5 & $67 \leq n<73$ & 2 & $B+$ \\
\hline 6 & $73 \leq n<80$ & 5 & $B$ \\
\hline 7 & $80 \leq n \leq 100$ & 11 & $A$ \\
\hline
\end{tabular}

Dari hasil ini, didapat data bahwa sebagian besar peserta didik dapat mengerjakan ujian praktek dengan maksimal dan mendapatkan nilai yang cukup bagus.

\subsection{Rancangan pengajaran dan hasil pembelajaran sampai sebelum Ujian Akhir Semester}

Bertolak dari hasil ujian tengah semester yang cukup bagus, penulis menambahkan tingkat kesulitan pada rancangan bagian 2 yang sebelumnya telah disusun. Prinsip-prinsip pengajaran yang digunakan masih sama dengan prinsip pengajaran yang digunakan dalam rancangan pembelajaran sebelum ujian tengah semester, namun penulis menambahkan prinsip tujuan yaitu memilih latihan yang dapat lebih cepat mencapai tujuan dari inti materi. Metodemetode yang digunakan adalah metode ceramah, latihan keterampilan, diskusi, demonstrasi. Tugas-tugas yang diberikan kepada peserta didik mencakup:

1. Mempresentasikan unit kegiatan mahasiswa seperti klub basket, klub komik, dan lainlain secara berkelompok. Presentasi diadakan seperti ketika pengenalan unit kegiatan mahasiswa yang ada di kampus ini kepada mahasiswa baru.

2. Drama singkat dengan tema "mentraktir teman", "menelepon dan memesan makanan melalui layanan pesan antar", "meretur barang yang sudah dibeli ke toko".

3. Demonstrasi menjadi agen properti. Mahasiswa diminta untuk mengadakan presentasi untuk mengenalkan rumah/apartemen yang ingin disewakan atau dijual.

4. Bercerita dengan tema "cerita yang dapat menginspirasi orang lain".

Dengan total 13 pertemuan, ada beberapa tema yang mengharuskan peserta didik untuk lebih melatih keterampilan berbicara secara personal di depan peserta didik lainnya. Hal ini dilakukan dengan tujuan mereka dapat lebih terbiasa untuk tampil di depan orang lain sehingga keberanian mengungkapkan pendapatnya dapat lebih meningkat. Dengan presentasi yang ada, peserta didik juga diberikan kesempatan untuk memikirkan jawaban atas pertanyaan yang diajukan oleh peserta didik lainnya. Dalam kehidupan nyata, ketika seseorang mempresentasikan suatu materi, seseorang tersebut harus mempersiapkan diri dengan materi presentasi dan juga materi-materi lain yang bersangkutan. Oleh karena itu, peserta didik dapat lebih mempersiapkan diri dengan materi presentasi, kosakata dan kalimat yang berkaitan dengan materi presentasi, dan juga materi-materi lain yang bersangkutan. Di sini mahasiswa 
dituntut untuk dapat lebih membekali diri ketika tampil di depan orang lain. Selain tema presentasi yang lebih sulit, drama singkat juga diberikan dengan syarat-syarat penilaian yang lebih tinggi. Selain pengucapan, kosakata dan tata kalimat yang dipakai, peserta didik juga harus memperhatikan alur cerita, kelancaran berbicara, skenario, dan juga alat-alat pendukung lainnya seperti kostum dan lain-lain. Tugas ini diberikan agar sesuai dengan prinsip praktek dan prinsip komunikasi. Peserta didik selain dapat meningkatkan kemampuan komunikasinya, juga dapat lebih merasakan nuansa dan suasananya sebelum nantinya mereka menemukan halhal seperti ini di Tiongkok. Tugas terakhir adalah menceritakan cerita yang dapat menginspirasi orang lain. Di salah satu bab dalam seri buku ini, terdapat kutipan dari Einstein yang bunyinya sebagai berikut "Ketika manusia meninggalkan bangku sekolah, pengetahuan yang sudah dipelajari cenderung akan lupa, yang tersisa itu disebut dengan pendidikan ". Kutipan lain berasal dari Konfusius yang bunyinya "Tiga orang yang berjalan bersama, salah satu dari orang ini pasti ada yang bisa menjadi guru saya". Dari dua kutipan ini, penulis merasa selain mengajarkan pengetahuan kepada peserta didik, juga harus memberikan pendidikan kepada peserta didik, oleh karena itu tugas ini diberikan kepada peserta didik dengan tujuan ada sesuatu yang dapat diambil hikmahnya dari cerita-cerita yang mereka ceritakan. Mereka dapat belajar dari sesamanya melalui cerita. Rancangan dalam bab ini dapat mengubah fokus pembelajaran dari peserta didik kepada peserta didik. Selain itu, juga dapat melatih kemampuan peserta didik dalam mengolah cerita yang sudah mereka dapatkan dari video, koran, majalah, dan lain-lain dalam bahasa yang berbeda ke Bahasa Tionghoa. Peserta didik dapat memutuskan pemakaian kosakata, tata kalimat mana yang lebih tepat yang sesuai dengan ragam bahasa di dalam cerita. Tugas-tugas kecil yang diberikan selama proses belajar dan mengajar juga ada diskusi dan menjawab pertanyaan sesuai dengan materi teks. Selain tugas-tugas yang diberikan ini, di setiap akhir pertemuan, penulis memberikan latihan mengulang kalimat yang diucapkan oleh penulis. Di dalam ujian HSKK tingkat dasar dan terampil, ada satu bagian ujian berupa mengulang kalimat yang sudah diucapkan. Oleh karena itu, latihan ini diberikan untuk mempersiapkan mereka dalam mengikuti ujian HSKK.

Rancangan pembelajaran di atas selain menggunakan prinsip praktek, komunikasi, tujuan, juga menggunakan prinsip efektifitas waktu, karena itu tugasnya ada yang diberikan dalam bentuk kelompok dan personal. Sesuai dengan materi dan tugas yang sudah diberikan, penulis menyusun materi ujian akhir semester dengan rancangan sebagai berikut:

1. Mengulang beberapa kalimat yang sudah diucapkan oleh penulis.

2. Menjawab beberapa pertanyaan. 
3. Menceritakan cerita yang dapat menginspirasi orang lain.

Setelah ujian akhir semester didapatkan hasil ujian yang diuraikan dalam tabel di bawah ini:

Tabel 3: Hasil Ujian Akhir Semester mahasiswa/i semester Ganjil 2015/2016

\begin{tabular}{|c|c|c|c|}
\hline No & Standar nilai & Jumlah Peserta Didik & Transkip Nilai \\
\hline 1 & $\mathrm{n}<41$ & 1 & E \\
\hline 2 & $41 \leq \mathrm{n}<55$ & 3 & D \\
\hline 3 & $55 \leq \mathrm{n}<61$ & 3 & $\mathrm{C}+$ \\
\hline 4 & $61 \leq \mathrm{n}<67$ & 2 & $\mathrm{C}$ \\
\hline 5 & $67 \leq \mathrm{n}<73$ & 3 & $\mathrm{~B}+$ \\
\hline 6 & $73 \leq \mathrm{n}<80$ & 3 & B \\
\hline 7 & $80 \leq \mathrm{n} \leq 100$ & 7 & A \\
\hline
\end{tabular}

Dari hasil ujian tengah semester, ternyata sebagian besar mahasiswa mengalami penurunan prestasi. Sebanyak 77\% mahasiswa mengalami penurunan nilai. Dilihat dari rancangan pengajaran semester yang telah dibuat dan dari hasil proses belajar dan mengajar dalam kelas, didapat hasil bahwa peserta didik tidak dapat menerima materi dengan maksimal.

\section{SIMPULAN DAN SARAN}

Teknik pengajaran keterampilan berbicara Bahasa Tionghoa sebagai bahasa kedua banyak digunakan oleh pengajar asing di luar negara Tiongkok untuk meningkatkan efektifitas pembelajaran. Namun pengajar harus memperhatikan faktor lain seperti ruang kelas, jumlah pertemuan, jumlah peserta didik dan lain-lain. Teknik pengajaran ini bila dikombinasikan dengan baik akan sangat meningkatkan kualitas pengajaran.

Dilihat dari hasil proses pengajaran dan pembelajaran dalam mata kuliah percakapan 3 ini, peserta didik cukup maksimal dalam menerima materi ajar dan dapat memberikan hasil yang cukup baik juga ketika diuji dalam ujian tengah semester. Namun, peserta didik kurang maksimal dalam menerima materi yang diberikan sesudah ujian tengah semester. Hal ini disebabkan oleh meningkatnya tingkat kesulitan praktik latihan yang diberikan.

Teknik pengajaran yang digunakan penulis memang tidak bisa dibilang sempurna, ada beberapa hal yang luput dari pertimbangan penulis, yaitu kondisi ruang kelas yang kurang mendukung latihan drama, serta tatanan kursi yang terlalu fokus di pengajar, sehingga kurang mendukung untuk diskusi, dan lain-lain. Jumlah pertemuan juga terbatas untuk latihan praktek yang cukup lama karena jumlah peserta didik yang berjumlah 22 orang. Satu hal lagi yang luput dari pertimbangan adalah jumlah peserta didik yang cukup banyak sehingga penulis tidak bisa memastikan perkembangan setiap peserta didik. 
Selain teknik pengajaran yang bervariasi, pengajar juga harus memiliki kemampuan untuk membawakan suasana. Bagaimana membawa suasana kelas agar menjadi lebih serius, lebih santai, lebih menyenangkan sangat bergantung pada kepintaran guru dalam membawakan suasana kelas.

Tentunya penelitian yang dilakukan oleh penulis ini masih jauh dari kata sempurna karena tidak menyertakan kuisioner dari peserta didik mengenai hasil evaluasi proses belajar dan mengajar di dalam kelas. Saran penulis untuk pengajar lain yang memiliki bidang ilmu yang sama dapat menjadikan penelitian ini sebagai referensi pengajaran.

\section{DAFTAR PUSTAKA}

Wu, Yongy (吴勇毅). 2003. Dui wai hanyu jiao xue ketang jiaoan sheji. Sinolingua.

Zhao, Jinming (赵金铭). 2010. Hanyu zuo wei di er yuyan jineng jiao xue. Beijing University Press.

Zhao, Jinming (赵金铭). 2010. Hanyu zuo wei di er yuyan yaosu jiao xue. Beijing University Press.

Zhiying, Lu (路志英). 2011. Developing Chinese Intermediate Speaking Course I $2^{\text {nd }}$ Edition. Beijing Languange and Culture University Press.

\section{Data Penulis}

$\begin{array}{ll}\text { Nama } & \text { : Preyi Vencania Lumanda } \\ \text { Program studi } & : \text { Sastra Cina } \\ \text { Jurusan } & : \text { Sastra Cina } \\ \text { Perguruan Tinggi } & : \text { Fakultas Sastra Universitas Kristen Maranatha } \\ \text { Hp } & : \text { +6281321122988 } \\ \text { Email } & : \text { preyivencania@gmail.com }\end{array}$

